7. Назипа Сагызбаевна Кульжанова (1887-1934) - первая казахская журналистка [Текст] // История Восточного Казахстана с начала XX века до современности: хрестоматия для 9 класса общеобразовательных школ ВКО / сост. Д. И. Бралинова [и др.]. - Семей : Тенгри, 2013. - С. 172-174.

8. Getahun Z, et al. Review of the status of malnutrition and trends in Ethiopia. The Ethiopian Journal of Health Development (EJHD) 2017;15(2) [Google Scholar] [Ref list].

9. Скутерис Х., МакКейб М., Суинберн Б., Ньюгрин В., Захер П., Чедвик П. Влияние родителей и профилактика ожирения у дошкольников: систематический обзор вмешательств . 2011 г . ; 12 (5): 315-28.

10. Ахметова, Г. К. Исследование питания детей в дошкольных учреждениях в Западно-Казахстанской области // Молодой ученый. - 2015 . - $\quad$ № $6.3 \quad$ (86.3). - $\quad$ С. 14-19. Данная статья подготовлена в рамках научно-технической программы «Научные основы модернизации системы образования и науки».

\title{
Булдакова Н.Б. \\ Реализация краеведческого принципа в процессе подготовки учителей географии
}

ФГБОУ ВО «Шадринский государственньй педагогический университет»

(Россия, Шадринск)

doi: 10.18411/trnio-10-2021-03

\section{Аннотация}

Статья посвящена вопросам внедрения краеведческого принципа в учебновоспитательный процесс студентов, обучающихся по профилю «География». Автор обращает внимание на значение краеведческого принципа в подготовке будущих педагогов. В статье рассматриваются методы и приёмы внедрения краеведческого принципа в образовательный процесс. Приводятся примеры заданий для студентов краеведческого содержания.

Ключевые слова: краеведческий принцип, учебно-воспитательный процесс, география, краеведение, методы географических исследований.

\section{Abstract}

The article is devoted to the implementation of the local history principle in the educational process of students studying in the profile "Geography". The author draws attention to the importance of the local history principle in the training of future teachers. The article discusses the methods and techniques of introducing the local history principle into the educational process. Examples of tasks for students of local history content are given.

Keywords: local history principle, educational process, geography, local history, methods of geographical research.

На разных исторических этапах развития науки в понятие «краеведение» вкладывалось различное содержание. В 20-х годах XX в. оно рассматривалось как метод синтетического изучения какой-либо определённой, выделяемой по административным, политическим или хозяйственным признакам относительно небольшой территории. В $30-\mathrm{x}$ годах краеведение определялось как «общественное движение, объединяющее местное трудовое население, активно участвующее в соцстроительстве всего края на основе всестороннего его изучения» [1]. Были также высказывания о нём как об особой науке, предмете преподавания. Краеведением занимаются историки, естествоиспытатели, специалисты языка и литературы, архитектуры, работники искусств. Однако ни в какой другой науке оно не представлено так ярко как в географии. Барков А.С. считал, что «объект и методы изучения географии и краеведения совпадают». Поэтому нам представляется важным обязательное внедрение краеведческого принципа в процессе подготовки учителей географии [3].

Краеведение имеет ряд специфических особенностей, выделяющих его среди остальных направлений образовательной деятельности:

\section{- приоритет воспитательных задач;}

- возможности реализации принципов адаптивной педагогики; 
- интегративный характер содержания (многопрофильность содержательной стороны изучаемой территории: природа, хозяйство, экология, культура, история, современность и др.); применение общеучебных навыков познания и способов деятельности для формирования целостности взгляда на регион; практически неограниченный спектр возможностей использования и сочетания всех форм образовательной деятельности [2].

Всё это требует особого подхода к организации учебнопознавательной деятельности студентов, методике организации учебного процесса в вузах каждого региона.

Рассмотрим ряд возможностей реализации краеведческого принципа в учебном процессе в вузе на примере обучения будущих учителей географии.

Кафедра биологии и географии с методикой преподавания Шадринского государственного педагогического университета в течение двадцати лет занимается подготовкой учителей биологии и географии. За этот период сложился определённый опыт внедрения краеведческой деятельности в учебный процесс. Краеведческий принцип реализуется через ряд спецкурсов, национально-региональный компонент, деятельность в период полевых практик.

Преподавателями кафедры разработаны и внедряются в учебный процесс следующие спецкурсы и НРК: «География городов Курганской области»; «историческая и экономическая география Уральского региона»; «Биология и экология растительного и животного мира Курганской области»; «География Курганской области»; «Региональная экология», «Историческая география». В процессе изучения данных дисциплин студенты не только закрепляют полученные на фундаментальных дисциплинах знания и учатся использовать умения и навыки для решения географических задач и проблем регионального характера, но и получают большой объём знаний об особенностях своего края. Это формирует любовь к своей малой Родине, развивает познавательный интерес.

Целесообразно, чтобы преподавание данных дисциплин осуществлялось не только в аудитории и не сводилось лишь к изложению преподавателем теоретического материала. Отдельные занятия следует проводить в музее города, в городском архиве, в природных условиях. Так, например, в процессе изучения региональной экологии будет интересным для студентов исследование экологических показателей окружающей среды своего района (химический состав воды, почвы и т.д.).

Необходимо активное вовлечение студентов в процесс познания. Для этого могут быть предложены студентам такие виды работ как изучение архивных документов по определённой тематике; анализ статистических данных по населению и экономике в управлении статистикой города, работа с документами в музее города, изучение исторической литературы, посвящённой родному краю.

Большой интерес для краеведческих исследований студентов-географов представляют исторические города. Исторический город - это особый тип городских поселений, возникший в результате политических и экономических преобразований в государстве, необходимых для освоения нового пространства, и сохранивший богатое историкокультурное наследие, созданное несколькими поколениями горожан. Кроме того, в историческом городе на протяжении всего его существования сохраняются главные функции, не смотря на то, что функциональная структура подвергается трансформации. К категории исторических могут быть отнесены города различные по численности населения: крупнейшие, крупные, средние и малые. На территории Курганской области историческими городами являются Шадринск, Катайск, Далматово. В процессе изучения генезиса, развития, особенностей экономики исторических городов своего региона возникает возможность сформировать у студентов такие качества как приобщённость к общечеловеческим ценностям культуры, патриотизм, ответственность за свою родину. Кроме того, в процессе изучения студентами исторических городов возникает возможность организовать большое количество практических работ, где они получат значительный объём краеведческой информации, а также отработают и закрепят навыки применения методов географического 
исследования на практике. Исторический город может быть объектом исследования в период комплексной полевой практики по географии. Во время практики целесообразно предложить студентам следующий перечень заданий: исследовать функциональную структуру города и особенности её трансформации; выявить и охарактеризовать этапы социальноэкономического развития города; определить функциональную типологию города на разных этапах его исторического развития; составить прогноз о дальнейшем развитии города; предложить пути решения социально-экономических и экологических проблем города. Такая деятельность обычно вызывает интерес у студентов, так как они исследуют не абстрактный объект, а хорошо известный им город. Они получают большое количество неизвестной им ранее информации. Данный факт убеждает их в том, что даже известный, на первый взгляд, географический или социально-экономический объект может скрывать в себе много неизвестного. Это активизирует познавательный интерес студентов, приучает их к поиску, учит рассматривать географические объекты и социально-экономические структуры под различными углами зрения.

На кафедре биологии и географии с методикой преподавания краеведческий принцип в учебный процесс активно внедряется именно через исследование исторических городов. В процессе исследования студентами исторических городов используются следующие методы исследования.

\section{1. Методы получения и первичной обработки географической информации}

Наблюдение. Его сущность заключается в сборе первичной информации о географическом объекте путём непосредственного восприятия и выявления его характеристик в соответствии с целью исследования.

Результаты наблюдений фиксируются в виде таблиц, записей в полевой дневник, карточек, фотографирования, киносъёмки. Особым видом наблюдения является измерение, которое даёт информацию о количественных характеристиках объекта.

\section{Метод полевых исследований.}

Его сущность заключается в получении первичного фактического материала в низовых органах управления и непосредственном изучении территории для установления пространственной дифференциации населения и хозяйства, сопоставления взаимообусловленности природных и социально-экономических процессов. Полевые исследования включают сплошное обследование территории, маршрутные наблюдения и изучение типичных участков.

Опрос населения. Используется преимущественно в социально-географических исследованиях - когда статистическая и картографическая информация об изучаемом объекте отсутствует и надо узнать мнение людей о мотивах и причинах социальных явлений. Опрос может быть организован в форме беседы исследователя с опрашиваемым, при которой задаётся ряд целенаправленных вопросов для получения первичной информации. Второй формой опроса является анкетирование, которое может осуществляется путём непосредственной раздачи анкет, при помощи прессы, почтовой, телефонной, электронной связи. Результаты такой формы опроса зависят от правильности формировки вопросов в анкете.

\section{2. Методы анализа, систематизации и обобщения географической информации}

Описание. Под географическим описанием понимается упорядоченная характеристика территории, а также теоретическое обобщение полученного материала, т.е. систематизация, объяснение и построение теории.

Историко-географический метод. Используется для понимания современной территориальной организации общества. Его сущность заключается в исследовании всех изменений экономико-географических объектов, относящихся к разным историческим эпохам. С помощью этого метода можно проследить, как изменялась экономика 
определённого района, система расселения, выявить основные этапы хозяйственного оснащения территории [2].

Таким образом, использование краеведческого принципа в учебно-воспитательном процессе в вузе способствует лучшему усвоению материала, практически навыков работы с географическими объектами и расширяет кругозор студентов.

1. Рябова, Е.Ф. Краеведческий подход в обучении географии [Электронный ресурс]. https://solncesvet.ru/opublikovannyie-materialyi/kraevedcheskiy-podhod-v-obuchenii-geogra.111206/;

2. Строев, К.Ф. Методы и приёмы осуществления краеведческого принципа в преподавании географии [Электронный pecypc]. - https://www.bestreferat.ru/referat-394393.html;

3. Тишкова, Л.Н. Краеведческий подход в обучении географии [Электронный ресурс]. - Режим доступа: https://cyberleninka.ru/article/n/kraevedcheskiy-podhod-v-obuchenii-geografii/viewer;

4. Хольшина, М.А. Краеведческий принцип в преподавании всех курсов географии //Молодой учёный №24. 2016.

\section{Волегжанина И.С., Чусовлянова С.В. Онтолого-семантический метод обучения иностранному языку}

Сибирский государственный университет путей сообщения (Россия, Новосибирск)

doi: 10.18411/trnio-10-2021-04

\section{Аннотация}

В статье актуализируется проблема создания новых методов обучения иностранным языкам. Это обусловлено цифровыми трансформациями практически всех сфер человеческой деятельности в современном мире, включая образование. Проводится обзор традиционных методов обучения иностранным языкам. В частности, показываются различные толкования содержания коммуникативного метода. Новизна статьи заключается в том, что авторами предлагается метод обучения иностранным языкам, основанный на онтолого-семантическом подходе. Предлагаемый метод обращается к формированию и усвоению обучающимся понятий.

Ключевые слова: иностранный язык, метод обучения, онтолого-семантический подход, формирование понятий, цифровизация.

\section{Abstract}

The article highlights the problem of developing the new methods of teaching foreign languages. This is due to the digital transformations of almost all spheres of human activity in the modern world, including education. Traditional methods of teaching foreign languages are reviewed. In particular, different interpretations of a communicative method are shown. The article's novelty lies in the fact that the authors propose a method of teaching foreign languages based on an ontological-semantic approach. The proposed method appeals to the formation and acquisition of concepts by a student.

Keywords: foreign language, method of teaching, ontological-semantic approach, concept formation, digitalization.

В дидактике методы обучения трактуются как способы работы преподавателя с обучающимися. Метод обучения также представляется как модель процесса преподавания в некоторой учебной ситуации для решения конкретной учебной задачи. Для понимания сущности методов, используемых в преподавании иностранных языков, представляется полезным обратиться к существующим в педагогической науке классификациям методов. Наиболее известной является классификация методов, разработанная Ю. К. Бабанским [1]. Ученый предлагает выделять следующие основные группы методов обучения: словесные, 